\section{Scientific Journal of the Royal College of Science}

The students of the Royal College of Science are to be congratulated on their success in maintaining the publication of their Scientific Journal, printing some of the papers read during the session 1941-2 before the Chemical, Natural History and Mathematical and Physical Societies. This volume, the third to be issued in war-time and the twelfth of the series, maintains the high standard and variety of scientific interest of the previous volumes. The range of subjects covers electron diffraction and the electron microscope, graphical and mechanical methods of calculation, the chemistry of hashish and of acetylene alcohols, methane as an engine fuel, the nature of viruses, and luminescence in Crustacea, as well as a historical paper on Arrhenius, Ostwald and van't Hoff. Copies may be bought from the Sales Manager, Scientific Journal, Imperial College Union, London, S.W.7 (paper cover $4 s$., bound 5s. 6d. per copy).

\section{Introduction of Chinese Plants to Great Britain}

Few botanical explorers have surpassed the genius of Ernest Henry Wilson, who introduced the flora of China to Great Britain and North America. A short paper by E. H. M. Cox (J. Roy. Hort. Soc., 67, Pt. 11, November 1942) describes Wilson's expeditions to China, in the early years of this century, for the firm of James Veitch and Sons and later for the Arnold Arboretum. He visited the provinces of Hupeh and Zechwan, from which he introduced Davidia involucrata, Meconopsis integrifolia and a very large number of other species. Such well-known garden plants as Buddleia variabilis magnifica, Clematis Armandii, Berberis Wilsonoe, Thalictrum dipterocarpum and Viburnum Davidii, with several species of Rhododendron, Lilium and Abies, all owe their horticultural introduction to Wilson.

\section{Earthquakes Registered in India during 1940}

ACCORDING to seismological bulletins just received, numerous earthquakes were registered at the observatories of Agra, Bombay, Calcutta, Colombo, Dehra Dun, Hyderabad and Kodaikanal during the period July-December 1940 (Seism. Bull., July-Sept. 1940 and Oct.-Dec. 1940. Delhi : Government of India Meteorological Dept.). At Agra, 66 were registered during the period July-September and 75 during the remainder of the year. Again, noninstrumental reports of earthquakes sensible to human beings are an important feature of the reports. During the first quarter under discussion, 16 were reported to J. M. Sil, meteorologist at Poona, the shocks of greatest intensity being of scale 8 (RossiForel) and occurring on August 3 at Gulmarg, on August 8 at Gulmarg, on September 21 at the same place and also at Srinagar. During the second quarter, 11 earthquakes were reported as having been felt, the greatest intensity being 7 on the Rossi-Forel scale on two occasions. The first was at Bhuj on October 31, and the second at Srinagar on December 25.

\section{The Night Sky in February}

New moon occurs on February 4d. 23h. 29m. U.T. and full moon on February 20d. 05h. 45m. Conjunctions with the moon are as follows : Feb. 2d. 07h., Mars $5^{\circ}$ S. ; Feb. 3d. 15h., Mercury $0 \cdot 4^{\circ}$ N.; Feb. 6d. 10h., Venus $0 \cdot 5^{\circ}$ S.; Feb. 13d. 0lh., Saturn $4^{\circ}$ N. ; Feb. 16d. 03h., Jupiter $4^{\circ}$ N. Occultations of stars brighter than magnitude 6 are as follows: Feb. 12d. 19h. 24.7m., 179 B. Tauri $(D)$; Feb. 13d. 19h. 05.6m., 318 B. Tauri $(D)$; Feb. 24d. 05h.
$00 \cdot 3 \mathrm{~m} ., 65$ Virginis $(R)$. The times are given for Greenwich, and $D$ and $R$ refer to disappearance and reappearance, respectively.

There will be a total eclipse of the sun on February 4-5, invisible at Greenwich. The eclipse is visible in Japan, Alaska and the eastern parts of North America. There will be a partial eclipse of the moon on February 20 , partly visible at Greenwich. The magnitude of the eclipse is $0 \cdot 767$. The circumstances of the eclipse are as follows :

$\begin{array}{lccclll}\text { Moon enters penumbra } & \ldots . & \text { Feb. } 20 \mathrm{~d} . & 02 \mathrm{~h} . & \mathbf{4 3} \cdot 1 \mathrm{~m} . \\ & \ldots . & \ldots . & 20 & 04 & 03 \cdot 0 \\ \text { Mid̉dle of eclipse } & \ldots . & \ldots . & 20 & 05 & 38 \cdot 0 \\ \text { Moon leaves umbra } & \ldots . & \ldots . & 20 & 07 & 13 \cdot 0 \\ \text { Moon leaves penumbra } & \ldots . & 20 & 08 & 32 \cdot 4\end{array}$

Jupiter and Saturn are well placed for observation during the month. Mercury attains its greatest elongation west on Feb. 18, when it rises at $6 \mathrm{~h} .15 \mathrm{~m}$. in the latitude of Greenwich, about an hour before sunrise. Venus rises about an hour after the sun in the middle of the month and sets at $19 \mathrm{~h}$. Mars, in the constellation of Saggitarius, rises at $5 \mathrm{~h}$. $30 \mathrm{~m}$. about the middle of the month and is not well placed for observation. Comet Whipple is a naked-eye object and can be seen in the night or morning hours up to the time of sunrise. An ephemeris appeared in NATURE of Jan. 23, p. 106.

\section{Announcements}

ON the joint recommendation of the presidents of the Royal Society and the Institution of Civil Engineers, the James Alfred Ewing Medal for 1942 has been awarded to Dr. R. E. Stradling. The Ewing Medal is awarded annually for specially meritorious contributions to the science of engineering in the field of research.

THE Council of the Institute of Metals has awarded the Institute's Medal to Dr. Harold Moore, for "outstanding services to non-ferrous metallurgy". Dr. Moore has been director of the British NonForrous Metals Research Association since 1932. Following his training under Dr. J. E. Stead, he held metallurgical posts with industrial firms before joining, as chief metallurgist, the Research Department, Woolwich, of which he was director of metallurgical research during 1919-32. The Institute's Medal, which is offered to the Council of the Institute by the Mond Nickel Company, Ltd., for award annually, is of platinum; previous recipients have been Sir William Bragg, Sir Harold Carpenter, Dr. Paul Merica, Dr. C. H. Desch and Sir W. Murray Morrison. It will be presented to Dr. H. Moore at the annual general meeting to be held in London on March 3.

To commemorate the birth, on March 3, 1843, of the distinguished metallurgist, Sir William C̈handler Roberts-Austen, the Institution of Mechanical Engineers, the Iron and Steel Institute and the Institute of Metals have arranged a lecture on his life and work, to be given by Dr. S. W. Smith, on Wednesday, March 3, at 5.30 p.m. at the Institution of Mechanical Engineers, Storey's Gate, S.W.1. Sir W. C. RobertsAusten was an honorary member of the Institution of Mechanical Engineers and he conducted a notable series of researches for the Alloys Research Committee of that Institution; he was a past-president of the Iron and Steel Institute, and his name is perpetuated in the literature of ferrous metallurgy by the word 'austenite'. Dr. Smith, who in 1914 wrote a book "Roberts Austen; a Record of his Work", acted as Sir William's private assistant at the Royal Mint. No tickets are required for the lecture. 